\title{
卜
}

\section{Change in the Dynamic Mechanical Properties of Nylon 6 during Photodegradation with Light above $300 \mathrm{~nm}$}

\author{
by
}

Shoichiro YANO and Mikio Murayama

(Industrial Products Research Institute, 1-1-4, Yatabe-Mach

Higashi, Tsukuba-Gun, Ibaraki 305)

\begin{abstract}
Wavelength dependence of the photodegradation of nylon 6 was investigated by using spectrally dispersed light in the wavelength range of 300 and $550 \mathrm{~nm}$. On irradiation with light above $300 \mathrm{~nm}$, the dynamic modulus $E^{\prime}$ was increased at each wavelength between 300 and $500 \mathrm{~nm}$. From measurement of $[\eta]$ and X-ray diffraction, it was found that the increase in $E^{\prime}$ by irradiation was a result of crystallization accompanied by scission reaction between amide groups. Change in $E^{\prime}$ as a function of irradiation time was linear and was expressed by the equation, $E^{\prime}(t)=E_{0}{ }^{\prime}+k t$, where $E^{\prime}(t)$ is the dynamic modulus at time $t, E_{0}{ }^{\prime}$ is that at $t=0$, and $k$ is the rate constant. In the $\tan \delta$ versus temperature curve of nylon 6 irradiated at the wavelength above $300 \mathrm{~nm}$, the $\alpha$-relaxation $\left(85^{\circ} \mathrm{C}\right.$ ) was broadened and the intensity of the $\beta$-relaxation at $-45^{\circ} \mathrm{C}$ was lowered. However, behavior of the $\gamma$-relaxation $\left(-100^{\circ} \mathrm{C}\right)$ was not changed.
\end{abstract}

\section{ナイロン 6 の 300nm 以上での光劣化と動的粘弾性}

\author{
矢野彰一 郎・村山三 樹 男*
}

（原稿受理：1980年 2 月25日）

\section{1. 緒言}

ナイロン 6 に空気中で紫外線を照射すると, アミド基の切断, $\mathrm{NH}$ に刘する $\alpha$ 炭素からの水素の引き抜き，酸化に伴弓過酸化ラ ジカルの形成など種々の反応が起こることが知られている1) 3). しかし，その結果分子鎖の切断が起こる(4) 8) のか架橋が起こる゙2 のか研究者によって解釈が異なりあいまいである。これは使用さ れたランプによる差, すなわち照射した波長によって異なったも のと考えられる.

高分子の少化による分子鎖の切断や架橋は，動的弾性率などの 力学的性質によく反映されてくることはすでに報告しだ．前 報10) 12) に打いて，ナイロン 6 に分光された紫外線を照射すると 300nm 以下の波長で弹性率や密度が増大し，これは照射時間の関 数としての $[\eta]$ の增加やX線回折図に変化がないことから，架橋

* 通産省工業技術院製品科学研究所 茨城県筑波郡谷田部町東 $1-$ $1-4$
反応が結果として優勢に起こっていることがわかった．しかしな がら, 太陽光は $300 \mathrm{~nm}$ 以上の波長の光を含んでいる ${ }^{13)}$ ので, ナ イロン 6 を屋外で使用するという実際的な利用の観点から考觉る と, $300 \mathrm{~nm}$ 以上の光に上る少化の研究がより重要となる，本報で はナイロン 6 に $300 \mathrm{~nm}$ 以上の波長をもつ紫外線を照射し, 光劣 化の動的力学的性質に及ぼす影響をしらべた。

\section{2. 実 験}

試料は厚さ $30 \mu \mathrm{m}$ の東レナイロンCM1021を用いた。目安と して，〔ク〕を測定したのち式(1) ${ }^{14)}$ とより重量平均分子量を求める と 35,880 であった.

$$
M_{w}=22.3 \times 10^{3}[\eta]^{1.33}
$$

原試料は，熱や水分に不安定な擬似六方晶であるので，これを エタノール中で72時間煮沸することにより, 安定な $\alpha$ 型ナイロン 6 にしてから使用した。 


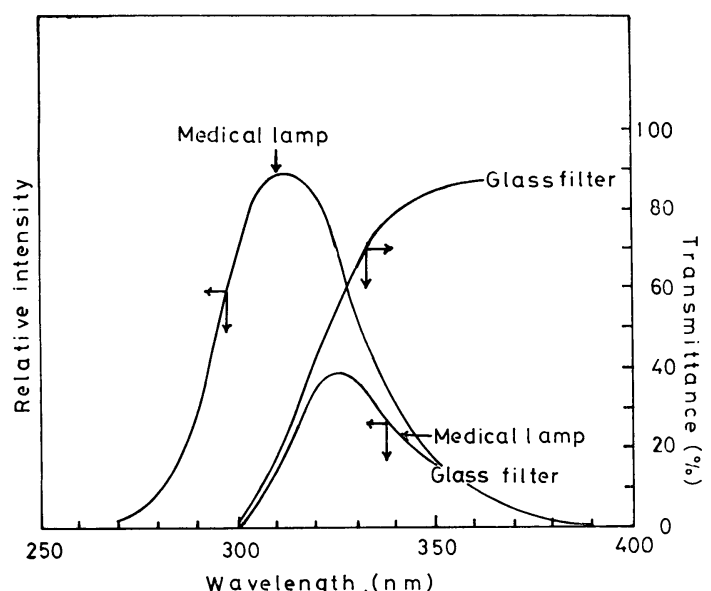

Fig. 1 Spectral energy distribution of a medical lamp and the glass filtered medical lamp, and transmittance of glass.

光少化の波長依存性をしらべるためには，2 $\mathrm{kW}$ キセノンラン プからの光をグレーティングにより分光して照射することのでき る日本分光 CRM-FA 型照射分光器を用いた，装置の詳細は前 報 ${ }^{12)}$ と示した。

[n]，X線，温度分散測定用の試料をつくるために, Fig. 1 の ような分光エネルギー分布をもつ東芝 FL-20E (医療用ランプ, 主波長 $310 \mathrm{~nm}, 20 \mathrm{~W})$ の $300 \mathrm{~nm}$ 以下の光をガラスでカットした 主波長が $325 \mathrm{~nm}$ のランプを用いて $60^{\circ} \mathrm{C}$ ，空気中で照射した。

$300 \mathrm{~nm}$ 以上の紫外線を照射しながら動的弾性率 $E^{\prime}$ の経時変化 を測定するためには， $500 \mathrm{~W}$ キセノンランプからの $365 \mathrm{~nm}$ 以下 の波長をフィルター（東芝色ガラスフィルター, UV-39）によっ てカットした光を用いた.

動的粘弾性の測定は, VIBRON DDV-IIC 型（東洋ボールド ウィン)により $110 \mathrm{~Hz}$ で行った。温度分散は昇温速度 $2^{\circ} \mathrm{C} / \mathrm{min}$ で測定した．X線回折は理学電機ローターフレックスにより $\mathrm{Ni}$ 口過した $\mathrm{CuK}_{\alpha}$ 線を用い, $30 \mathrm{kV}, 30 \mathrm{~mA}$ で測定した。〔ク]はメ タクレン゙ール中, $25^{\circ} \mathrm{C} て ゙$ 測定した.

\section{3. 実験結果と考察}

Fig. 2 は $60^{\circ} \mathrm{C} て ゙ ~ 300 \mathrm{~nm}$ 以上の分光された光を試料に照射し, 各照射波長每に動的弾性率の変化をプロットしたものである。縦 軸は未照射試料の $30^{\circ} \mathrm{C}$ に扔ける動的弾性率 $E_{\text {unirr. }}^{\prime}$ 、対する各照 射波長に抢ける動的弾性率 $E^{\prime}{ }_{\mathrm{irr}}$ の比としてあらわした. $300 \mathrm{~nm}$ 以上の長波長の光によっても 100 時間以上長時間照射することに より弾性率が増大寸ることがわかる. 約 $400 \mathrm{~nm}$ と $460 \mathrm{~nm}$ 付近 のピークはキセノンランプの分光ェネルギー分布 ${ }^{12}$ そ括ける 400 $\mathrm{nm}$ と $470 \mathrm{~nm}$ のピークによく対応している.すなわち, 光の強 度の高いところで大きく劣化していることがわかる. Table I ${ }^{3)}$ はポリアミドに含まれる各種の化学結合エネルギーとその効応す る波長を示した. $300 \mathrm{~nm}$ 以上では理論的には $\mathrm{C}-\mathrm{C}$ 結合なども切 れることになるが，実際には 300nm 以下の光でなければ切れな いことが知られている。したがって，300 $\mathrm{nm}$ 以上の光では主とし てアミド基の切断が起こっているものと考えられる. Fig. 2のよ らな照射による弾性率の増大には，架橋反応と分子鎖の切断に伴

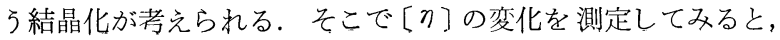

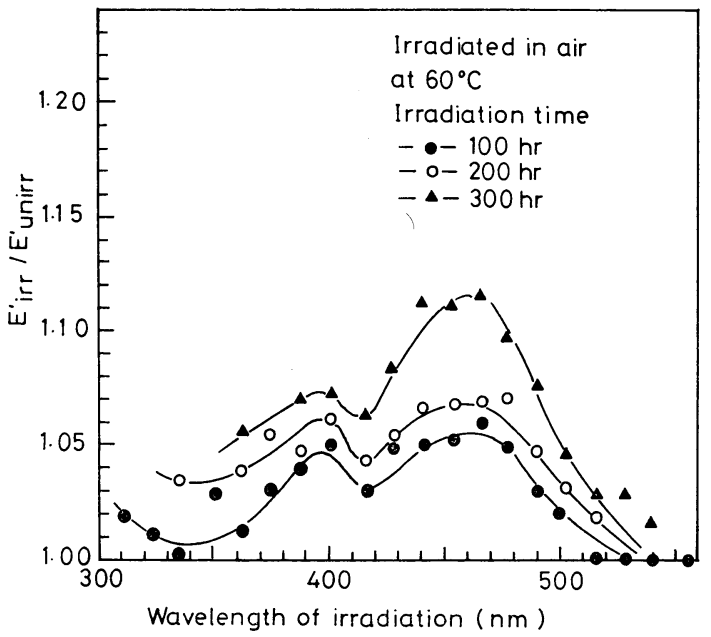

Fig. 2 Wavelength dependence of photodegradation on changes in the dynamic modulus.

Table I. Bond energies and corresponding wavelength.

\begin{tabular}{ccc} 
Chemical Bond & $\begin{array}{c}\text { Bond Energy } \\
\text { kcal/mole }\end{array}$ & $\begin{array}{c}\text { Wavelength } \\
\mathrm{nm}\end{array}$ \\
\hline C-N & 53.0 & 539 \\
C-C & 79.3 & 361 \\
C-O & 79.6 & 360 \\
& 82.2 & 350 \\
N-H & 92.0 & 311 \\
C-H & 98.7 & 290 \\
\hline
\end{tabular}

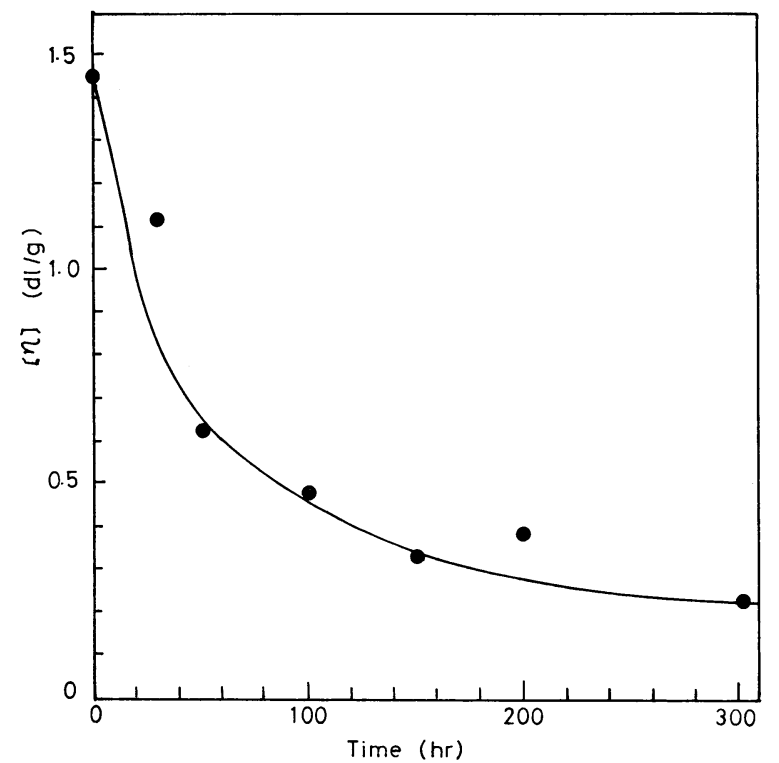

Fig. 3 Change in intrinsic viscosity during photodegradation at the wavelength above $300 \mathrm{~nm}$.

Fig. 3 のようになる。照射によって[ク]は $300 \mathrm{~nm}$ 以下の照射の 場合 ${ }^{12)}$ と逆に大きく減少し, 切断反応が優勢に起こっていること がわかる。このように照射によって[ク]が減少し，弾性率が增大 するといらことは，アモルファス領域で分子鎖の切断反応が起こ り，低分子化することにより結晶化が進行するためであると考党 


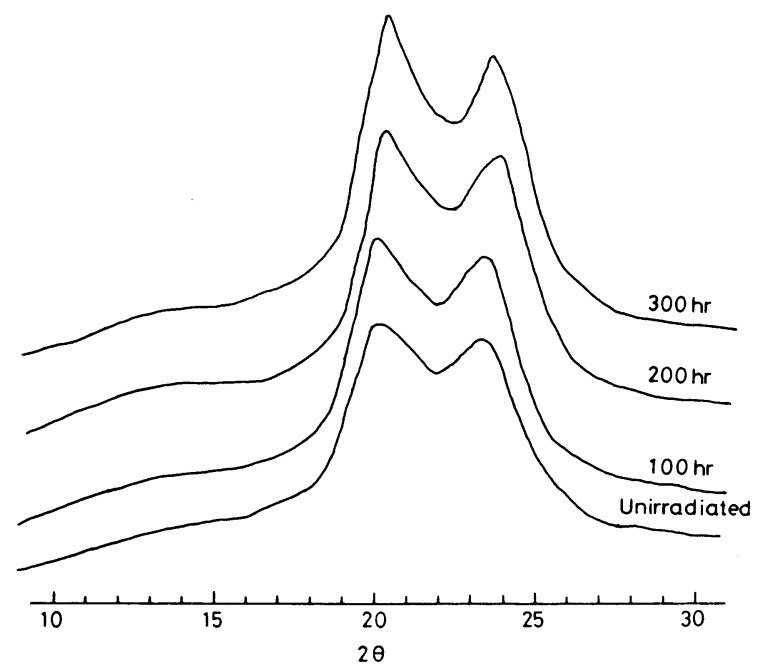

Fig. 4 X-ray diffraction pattern of unirradiated and irradiated nylon 6. Irradiation was done by using the glass filtered medical lamp at $60^{\circ} \mathrm{C}$ in air.

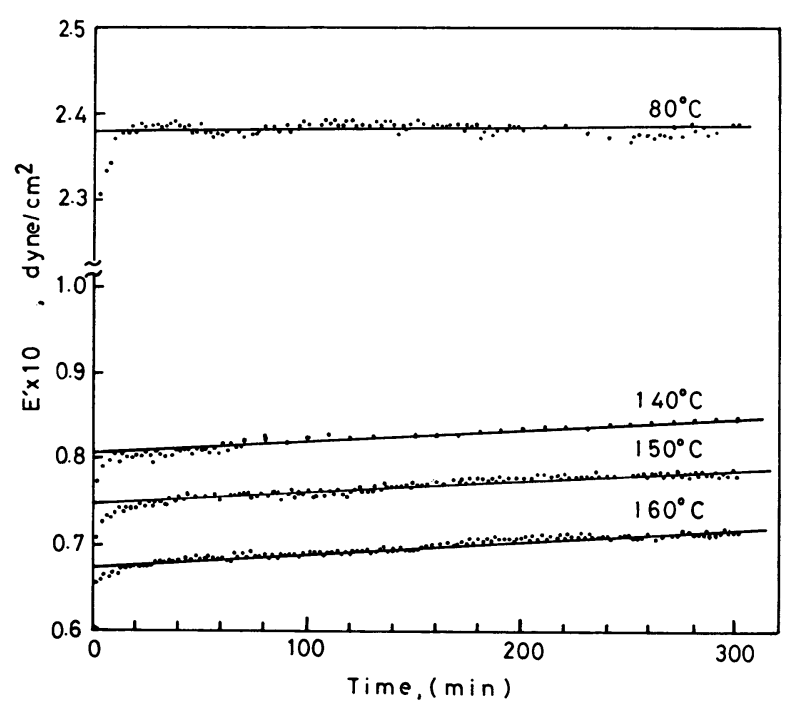

Fig. 5 Changes in $E^{\prime}$ with elapsed time during irradiation at the wavelength above $365 \mathrm{~nm}$.

られる．そこでX線回折図をとってみると Fig. 4 のようになる. 照射の進行に伴って $2 \theta=20^{\circ}$ の 200 面と， $2 \theta=24.0^{\circ}$ の 002,202 面のピークが明らかに增大していることがわかる，これらのこと から $300 \mathrm{~nm}$ 以上の光の照射により, それ程複雑な反応は起こら ずアミド基の切断と安定化, それに伴う結晶化が起こり架橋反応 は全く起こらないものと考兄られる。

次に, キセノンランプからの $365 \mathrm{~nm}$ 以下の波長をカットした 光を照射しながら， $E^{\prime}$ の経時变化を測定すると Fig. 5 のように なる． $E^{\prime}$ は照射時間と共に切断反応に伴う結晶化を反映して徐々 に直線的に増大することがわかる．これらの直線は式(2)のような 簡単な速度式で書きあらわすことができる.

$$
E^{\prime}(t)=E_{0}{ }^{\prime}+k t
$$

ここで, $E_{0}{ }^{\prime}$ は $t=0$ での $E^{\prime}, k$ は速度定数である.

このように $300 \mathrm{~nm}$ 以上の紫外線の照射によりアミド基の切断

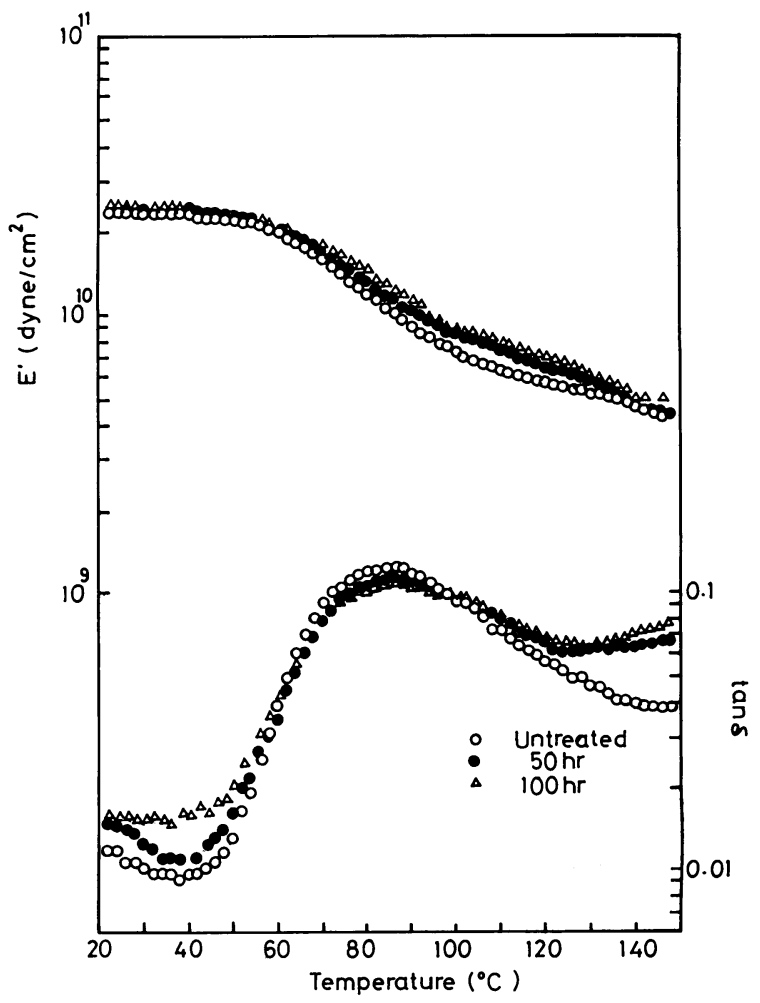

Fig. 6 Change in the $\alpha$-relaxation during the photodegradation by the glass filtered medical lamp.

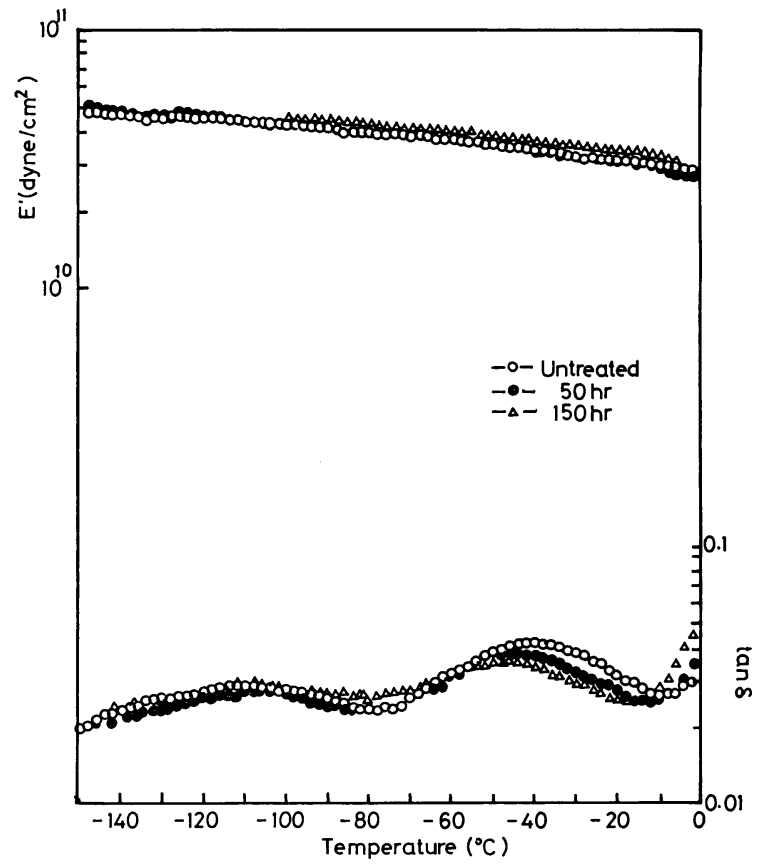

Fig. 7 Changes in the $\beta$ - and $\gamma$-relaxation during the photo-degradation by the glass filtered medical lamp.

による低分子化ととれに伴う結晶化が起こり, 結果として弾性率 を增大させることが認められたが，照射によるこのような構造の 変化がアモルファス領域に拄ける各種の分子運動を反映する $\alpha$, $\beta, \gamma$ などの緩和にどのよ5な変化を及ぼすかを知ることは興味 
がある. Fig. 6 は 300nm 以上の光で劣化させた試料と未照射試 料の乾燥状態での $\alpha$ 分散を比較したものである. 照射によって $\alpha$ 分散はブロードになる。 これはアモルファス領域に切断反応と低 分子化によって生じた結晶が分子鎖のセグメント運動を束ばくす るためと考兄られる. この効果は $300 \mathrm{~nm}$ 以下の照射によって生 じる架橋によるそれ(2) と同じである。ナイロン 6 の $\beta$ 分散は試料 が吸湿すると発現する，そこで， $300 \mathrm{~nm}$ 以上の光で劣化した試料 と末照射試料を飽和食塩水を入れたデシヶーター中 $30^{\circ} \mathrm{C}$. (RH 76 \%)で 7 日間調湿したものについて， $\beta$ 分散と $\gamma$ 分散を測定する と Fig. 7 のようになる. アモルファス領域に捣けるメチレン基 の運動を反映する $\gamma$ 分散 ${ }^{15)}\left(-100^{\circ} \mathrm{C}\right)$ は照射によって変化しな かった. $-45^{\circ} \mathrm{C}$ に生じる $\beta$ 分散（その起因については種々の説が あるが，例兊ば Illers ら ${ }^{16)}$ は水の結合したアミド基の運動として いる）は, 300nm 以上の光の照射によりピークの高さが減少する.

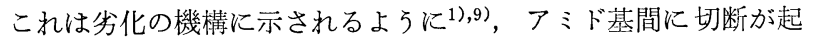
こることによりアミド基の数が減少するためと考兄られる. $E^{\prime} は$ アモルファス領域内の分子鎖の切断に伴う結晶化により, 分子鎖 の運動が束ばくされ全温度範囲にわたって增大する。

付記 本研究は工業技術院各研究所の共同研究「高分子材料の 耐久性」の一環として実施されたものである.

（1979年10月24日 第27回レオロジー討論会に括いて一部発表 した.)

\section{文献}

1) Rånby, B., and J.F. Rabek, "Photodegradation, Photooxidation and Photo-stabilization of Polymers", p. 236 (1975), John Wiley and Sons, New York.
2）ネイマン著，稲葉弥之助，飯山比呂美共訳，“高分子の劣 化一その機鹊と防止法—”, p. 201 (1967), 産業図書.

3) Stowe, B.S., R.E. Fornes, and R.D. Gilbert, Polym. -Plast. Technol. Eng., 3, 159 (1974).

4) Achhammer, B.G., F.W. Reinhart, and G.M. Kline, $J$. Res. Nat. Bur. Stand., 46, 391 (1951).

5) Goodman, J., J. Polym. Sci., 13, 175 (1954).

6) Moore, R.F., Polymer, 4, 493 (1963).

7) Stephenson, C.V., J.C. Lacey, Jr., and W.S. Wilcox, J. Polym. Sci., 55, 477 (1961).

8) Heuvel, H.M., and K.C.J.B. Lind, J. Polym. Sci., A-2, 8, 401 (1970).

9）矢野彰一郎, 村山三樹男, 中田外治, 大野正美, 第23回 $レ$ オロジー討論会講演要旨集, p. 93 (1975), 矢野彰一郎, 村山三樹男，吉田政夫，高分子論文集，32，288（1975）.

10）矢野彰一郎，村山三樹男，日本レオロジー学会誌， 7, 34 (1979).

11) Yano, S., and M. Murayama, Polym. Preprints, 20, 964 (1979).

12) Yano, S., and M. Murayama, J. Appl. Polym. Sci., to appear，矢野彰一郎，村山三樹男，第26回レオロジー討論 会要旨集, p. 133 (1978).

13）例えば, Hirt, R.C., and N.Z. Searle, Appl. Polym. Symposia, No. 4, 61 (1971).

14) Turzar Z., P. Kratochivil, and M. Bohdanecký, J. Polym. Sci., Part C, 16, 633 (1967).

15) Woodward, A.E., J.A. Saner, C.W. Deeley, and D.K. Kline, J. Colloid Sci., 12, 363 (1957).

16) Illers, K.H., Makromol. Chem., 38, 168 (1960). 